\title{
Licenciados e licenciadas em Ciências Sociais na UFSC: Experiências, sentidos e trajetórias
}

Eduardo Vilar Bonaldi

\section{Resumo}

Este artigo busca abordar e reconstruir trajetórias sociais, educacionais e acadêmicas de licenciados e licenciadas no curso de Ciências Sociais da UFSC, partindo de um material de 12 entrevistas em profundidade com egressos do curso durante os anos 2000. Primeiramente, abordamos as diferenças quanto à dinâmica de "escolha" da licenciatura em Ciências Sociais entre entrevistados de diferentes origens socioeconômicas, atentando, conforme aponta a literatura, tanto para os "reajustamentos de expectativas" que podem conduzir a carreiras de menor prestígio social quanto para experiências de socialização singulares que inculcam, em alguns dos entrevistados, propensões e interesses específicos por nossa carreira. Posteriormente, discutimos algumas questões que foram indistintamente tematizadas por diferentes perfis socioculturais de entrevistados, entre elas, por exemplo, a temática dos "ganhos não materiais" que os entrevistados associam recorrentemente à formação em Ciências Sociais, a despeito das dificuldades de profissionalização reiteradamente afirmadas por eles.

Palavras-chave: Socialização. Trajetórias educacionais. Licenciatura. Ciências Sociais.

\section{Introdução}

Entre o segundo semestre de 2017 e o primeiro semestre de 2018, o Núcleo de Estudos sobre Juventude e Cultura (NEJUC) do Departamento de Sociologia e Política da Universidade Federal de Santa Catarina (UFSC) conduziu uma experiência de pesquisa coletiva, integrando estudantes de

I Professor Adjunto no Departamento de Sociologia e Ciência Política da Universidade Federal de Santa Catarina (UFSC).E-mail: eduvilarbon@gmail.com.

$((\infty))$ EY
Direito autoral e licença de uso: Este artigo está licenciado sob uma Licença Creative Commons. Com essa licença você pode compartilhar, adaptar, para qualquer fim, desde que atribua a autoria da obra, forneça um link para a licença, e indicar se foram feitas alterações. 
graduação e de pós-graduação em Ciências Sociais, sob a coordenação dos Professores Eduardo Bonaldi e Amurabi Pereira².

Essa experiência de pesquisa consistiu na condução de 19 entrevistas semiestruturadas e em profundidade com licenciados e licenciadas em Ciências Sociais ${ }^{3}$, em nossa universidade, durante os anos 2000.

Todas as etapas da pesquisa foram realizadas durante os encontros quinzenais do NEJUC ao longo desse período. As etapas da pesquisa dividiram-se em: A) revisão de literatura, B) discussão de perspectivas teóricas mobilizadas, C) concepçáo do roteiro de perguntas, D) realizaçáo de três entrevistas preliminares, E) discussão das entrevistas preliminares, F) Realização das demais entrevistas, G) Transcrição do material e preenchimento de fichas de resumo de cada entrevista e, finalmente, F) Interpretação do material de entrevistas.

Todas as etapas da pesquisa foram conduzidas através da participação e da deliberaçáo coletiva entre os participantes do núcleo. Nesse sentido, essa experiência objetivou, portanto, a realização coletiva de um estudo que provesse, aos estudantes que integram o núcleo, a oportunidade de tomar parte ativa na concepção e na condução das diferentes etapas de uma pesquisa de caráter qualitativo.

Dessa maneira, o referido exercício de pesquisa produziu, como veremos, uma reflexão empiricamente informada sobre as condiçóes e trajetórias (sociais e acadêmicas) que caracterizam experiências, sentidos e trajetos vivenciados antes, durante e após a licenciatura em Ciências Sociais (doravante, CS) na UFSC.

Desse modo, ao entrevistar licenciados e licenciadas em CS na UFSC, os estudantes e os professores envolvidos no projeto foram impelidos a refletir sobre os condicionantes socioeconômicos e culturais que atuam

2 Deixo aqui um agradecimento tanto aos estudantes de pós-graduação (Marcelo Cigales, Treicy Giovanella, Tsamiyah Levi, Luana Lopes, Diego Greinert, Carolina Nascimento e Ana Martina Baron Engerohoff) quanto aos estudantes de graduação (Anderson Gabriel Cordeiro, Caroline Stresser, Sabrina Smialouski, Diane Macedo e Inaê Barbosa) que participaram de diferentes etapas do projeto.

30 presente artigo fundamenta-se nas transcrições de 12 entre as 19 entrevistas, uma vez que as outras sete transcrições e os resumos de entrevistas ainda estavam sendo elaborados pelo grupo quando ocorreu o convite para a contribuição com o presente dossiê. 
sobre A) a escolha e entrada no curso por parte dos entrevistados, B) suas experiências dentro do curso e os sentidos que associam a ele e, por fim, C) a projeção dos destinos sociais e ocupacionais enxergados como "possíveis” ou "desejáveis” pelos entrevistados após a obtenção do diploma.

De fato, o projeto buscou indagar como diferentes e múltiplos condicionantes sociológicos podem modular diferentes itinerários, experiências e sentidos associados pelos entrevistados ao "antes", ao "durante" e ao "após" a licenciatura em CS.

Com o intuito de expor os condicionantes sociológicos que levamos em conta tanto para a formulaçáo de nosso roteiro de perguntas, quanto para a elaboração de nossas "estratégias de entrevistas", provemos uma descrição sintetizada de tais condicionantes. Ademais, também é necessário afirmar que, em virtude da pouca experiência na condução de entrevistas em profundidade por parte dos estudantes, longas discussóes foram feitas para antecipar e simular recursos e estratégias que os estudantes poderiam empregar para estimular os entrevistados a tematizar questóes e assuntos de interesse da pesquisa, associados aos condicionantes sociológicos expostos logo em seguida ${ }^{4}$.

Segue, a seguir, a descrição sintetizada dos condicionantes sociológicos previstos no roteiro de perguntas:

A) incorporação de diferentes estruturas familiares de capital (econômico e cultural, sobretudo) sob a forma de diferentes propensóes comportamentais e de diferentes "horizontes" de destinos ocupacionais vistos como "possíveis" ou "desejáveis" pelos entrevistados após a titulação;

B) seus diferentes trajetos escolares (em estabelecimentos públicos ou privados, por exemplo) até a escolha da licenciatura em CS na UFSC;

C) a evolução das redes de relaçóes dos entrevistados antes, durante e após o curso, bem como seus possíveis efeitos sobre as trajetórias sociais ou educacionais desses entrevistados;

4 Tais discussões foram particularmente produtivas quando, durante o periodo de realização das entrevistas, os estudantes expunham, nas reuniões do núcleo, as dificuldades concretamente experienciadas por eles em algumas dessas entrevistas. 
D) a relevância que dinâmicas de socialização por gênero, bem como diferenças culturais associadas a identidades ou classificaçóes étnicas e raciais, podem assumir sobre escolhas e experiências acadêmicas e ocupacionais;

E) a relevância que a origem em metrópoles urbanas ou cidades, médias e pequenas, do "interior" (dentro ou fora do estado de Santa Catarina) pode assumir sobre escolhas e experiências acadêmicas e ocupacionais.

Ao contrário dos interessantes surveys sobre características socioeconômicas e culturais de nosso alunato, conduzidos durante a primeira década dos anos 2000 (LUCHMANN, 2006; MICK; Diamanto; Luz, 2012), nós optamos por um estudo de natureza e de objetivos qualitativos. Nesse sentido, portanto, o objetivo de nossa pesquisa não é a elaboração de afirmações sobre quais seriam os perfis discentes "médios" ou "majoritários" entre o alunato de CS na UFSC ${ }^{5}$. A natureza qualitativa do estudo nos endereça, com efeito, a objetivos de outra ordem.

Assim, nosso estudo busca evidenciar como os próprios entrevistados tematizam a interação entre os condicionamentos sociológicos acima descritos em suas próprias experiências e trajetos. Isto é, a pesquisa busca apreender como os entrevistados percebem e elaboram a forma como renda e escolaridade de suas famílias, suas redes de relaçôes, trajetos escolares, gênero, raça ou origens urbanas/rurais se organizam e se articulam nas narrativas e nas percepçóes que esses entrevistados expressam sobre suas vivências sociais e acadêmicas.

Ao lidar com o material das 12 entrevistas transcritas, o estudo torna-se capaz, portanto, de apreender e de elaborar oposiçóes e paralelismos entre diferentes perfis socioeconômicos e culturais de entrevistados ao longo de nosso trabalho de transcrição, de resumo e de interpretação do material de entrevistas referido.

Desse modo, portanto, nossa opção pelo estudo qualitativo nos faculta a capacidade de apreender e de descrever oposiçóes sociologicamente mais ricas e densas do que perfis estatísticos "medianos" ou "majoritários".

5 Apesar de nossa opção qualitativa, seria interessante que um survey sobre estudantes fosse novamente empreendido dado o espaço de quase uma década que já nos separa dos últimos questionários aplicados sobre nosso alunato. $\mathrm{O}$ uso de dados recolhidos pela universidade no momento do vestibular também poderia ser interessante. 
Nesse sentido, a interpretação do material de entrevistas será organizada e exposta em dois momentos ao longo deste artigo. $\mathrm{O}$ primeiro deles refere-se às diferenças quanto à dinâmica de entrada e de escolha da licenciatura em CS entre entrevistados de diferentes origens e trajetórias socioeconômicas.

Já o segundo momento do texto discute as experiências e os sentidos vivenciados pelos entrevistados durante a formação em CS na UFSC. Nesse ponto, tanto oposiçóes de perfis de entrevistados (entre estudantes que trabalham ou não ao longo do curso, por exemplo) quanto questóes tematizadas indistintamente por entrevistados de diferentes perfis (como os "ganhos não materiais" associados à formação em CS) serão abordadas e discutidas.

Por questóes de espaço, não foi possível discutir, no presente texto, as oposiçóes e os paralelismos entre perfis de entrevistados que seguem diferentes destinos ocupacionais após o curso. Essa questáo, longamente abordada durante as entrevistas, será tratada por textos que estão sendo produzidos pelos próprios estudantes envolvidos na pesquisa.

A perspectiva teórica que organiza e informa o estudo está apoiada na Sociologia bourdiesiana. Mobilizada para a reconstrução das trajetórias sociais, escolares e acadêmicas de nossos entrevistados, tal perspectiva supóe a existência e a provável transmissão intergeracional (por meio da socialização familiar) de "capitais" pertinentes às situaçôes de interação e de concorrência em diferentes campos ou espaços sociais. Esses diferentes capitais (econômico, cultural, social e simbólico) seriam acumulados em volumes e em estruturas desiguais entre grupos familiares inscritos em diferentes condiçóes sociais de existência, ou seja, em diferentes posiçóes relacionais no espaço social (Bourdieu, 1996).

Essas estruturas e os volumes de capitais, acumulados por um grupo familiar, são tendencialmente transmitidos às geraçóes mais jovens dessa família por meio dos laços afetivos que conduzem a socialização implícita, cotidiana e inconsciente por meio da qual essas condiçóes objetivas de existência social, acumuladas pelos grupos familiares, tendem a ser incorporadas sob a forma de uma matriz de geração e de unificação de padrôes de ação, gostos e juízos sociais tendentes à reprodução de tais condiçóes objetivas, isto é, o "habitus". 
Do ponto vista metodológico, ao contrário de muitos estudos que exercitam a técnica das entrevistas em profundidade, nossa pesquisa optou por náo acessar os entrevistados pelo conhecido método "bola de neve"6. Evitamos aplicar esse meio convencional de acesso a entrevistados em função do seguinte receio: ao rodar a "bola de neve" a partir de contatos dos pós-graduandos envolvidos no projeto, receávamos acessar tão somente contatos excessivamente endógenos às redes de relaçôes desses estudantes, ou seja, contatos que também fossem, eles próprios, pós-graduandos, impedindo, desse modo, que a pesquisa conseguisse acessar entrevistados e entrevistadas com outras experiências e, sobretudo, outros destinos sociais e ocupacionais após a diplomação.

Para contornar tal receio, obtivemos, junto à Secretaria do Curso, uma lista de todos os diplomados e diplomadas na licenciatura durante os anos 2000. Procedemos, entáo, sorteios sequenciais de nomes nessa lista, encaminhando aos sorteados mensagens de e-mail que explicavam rapidamente o teor da pesquisa, convidando-os à possível colaboração com o estudo por meio de uma entrevista. Havendo resposta e aceite por parte da pessoa contatada, após esclarecimentos adicionais sobre o teor da pesquisa e da proposta de entrevista, buscávamos agendar um horário e local conveniente a entrevistados e entrevistadas. Um termo de consentimento para a participação no estudo também era apresentado e explicado previamente ao entrevistado.

Os estudantes engajados no projeto foram divididos em quatro trios. Cada um desses trios contavam, ao menos, com um pós-graduando, responsável por sua coordenação, e com estudantes de graduação de diferentes semestres do curso. Cada trio ficou encarregado de acessar, agendar, conduzir, transcrever e resumir, ao menos, três entrevistas em profundidade. Em geral, essas entrevistas eram conduzidas por um ou dois estudantes de cada trio.

A realização das entrevistas, geralmente em duplas, foi reportada pelos estudantes como um recurso produtivo para compensar a ansiedade

6 Ou seja, método a partir do qual se busca solicitar, a entrevistados, indicações de conhecidos seus que poderiam colaborar com a pesquisa, concedendo, eventualmente, outras entrevistas. 
e a inexperiência no exercício dessa técnica de pesquisa; afinal, os dois estudantes apoiavam-se e se complementavam nas múltiplas e sincrônicas tarefas que sempre acabam por envolver a complexa condução de uma boa entrevista em profundidade: "vigiar" a tematização integral do roteiro apesar dos "saltos" e inversôes de ordem próprios à situação mais fluída das entrevistas "semiestruturadas", retomar o roteiro após digressôes ou "fugas" de tema por parte do entrevistado, improvisar estratégias para a tematização de questóes mais sensíveis, vigiar a irrupção de situaçóes emocionalmente delicadas, detectar incongruências narrativas solicitando esclarecimentos ao entrevistado, manejar o controle do tempo de entrevista etc. (ARENDEL, 1997).

Como sabemos, toda entrevista é, inescapavelmente, uma interação ou um encontro social. Nesse sentido, a literatura sobre metodologia qualitativa nos recomenda incessantemente o exercício de reflexividade, atenta e metódica, sobre a forma como as estruturas das situaçóes interacionais de entrevistas podem modular sentidos e narrativas expressos pelos entrevistados (MALINOWSKI, 2002; BECKER, 1999; Pialoux; Beaud 2009; SMALL, 2009).

Sendo assim, também é digno de nota metodológica o fato de que, nas situaçôes de interação articuladas nas entrevistas, os entrevistados, detendo conhecimentos e diplomas em CS, colocam em marcha prática e efetiva seu treinamento sociológico, buscando, com frequência, "descobrir" a intenção de uma determinada pergunta dos entrevistadores, "confirmar" suas suspeitas quanto a conceitos e teorias que informariam a pesquisa, fazer piadinhas sobre o que eles, como sociólogos, deveriam ou não dizer em uma entrevista como aquela, sugerir delicadamente que estávamos fazendo as "perguntas erradas" etc.

Dessa maneira, buscamos exercitar, durante a interpretação do material de entrevistas, a reflexividade metodológica, recomendada pela literatura, acerca dessa peculiar situação interacional ao longo da qual estudantes de CS entrevistaram licenciados e licenciadas na área conforme será notado ao longo do texto. 


\section{Antes da licenciatura em Ciências Sociais: origem sociocultural e escolha do curso}

Em "Os Herdeiros", Bourdieu e Passeron (1964, p. 13) evidenciam como a origem sociocultural (indicada pela ocupaçáo dos pais) estabelecia não somente probabilidades distintas de acesso ao Ensino Superior (ES, doravante), como também se transmutava em chances desiguais de acesso a carreiras universitárias hierarquizadas por diferentes graus de prestígio social.

Dessa maneira, filhos e filhas de profissionais liberais e de quadros superiores (em empresas/órgãos públicas ou privadas) demonstravam, portanto, não apenas maiores probabilidades de acesso ao ES, como também reuniam maiores chances de acessá-lo a partir de suas carreiras socialmente mais prestigiadas.

Longe de se inscrever como uma característica particular do sistema universitário francês da década de 1960, a literatura na área evidencia que, mesmo em momentos de expansão dos sistemas universitários nacionais, a origem sociocultural continua a estabelecer diferentes chances de entrada no sistema, bem como em diferentes carreiras hierarquizadas dentro desse sistema. No contexto brasileiro de recente expansão do sistema universitário, por exemplo, pesquisas recentes documentam como perfis sociais e raciais desprivilegiados tendem a alcançar o sistema a partir de suas carreiras socialmente menos valoradas (Ribeiro; Schlegel, 2015).

As Ciências Sociais (CS) - bem como as licenciaturas em geral - integram o conjunto de carreiras universitárias menos valoradas, do ponto de vista social ou profissional, tendendo a recrutar ingressantes entre camadas socioeconômicas mais "modestas" em comparação às carreiras fortemente elitizadas em instituiçóes públicas, tais como Medicina, Direito, Engenharias ou Administração, por exemplo.

Tal constatação está fortemente ilustrada em nossa amostra: apenas uma entrevistada entre os 12 licenciados e licenciadas que colaboram com o estudo declara ter os dois pais com ES (ensino superior) completo.

É justamente por esse caso que iniciaremos, portanto, nosso trabalho de descrição e interpretação do material de entrevistas: como veremos, a 
entrevistada Joana ${ }^{7}$ personifica as condiçôes socioculturais de maior familiaridade e proximidade à realidade do ensino universitário e, mais especificamente, da UFSC em nossa amostra.

Em seguida, acompanharemos os perfis de entrevistados cujos pais não possuem ES, mas se caracterizam por certa ascensão social e econômica a partir da qual conseguem oferecer condiçóes materiais e culturais que apoiam a entrada de seus filhos como a primeira geração desses grupos familiares no ES.

Essas são as histórias de Tiago, filho de um eletricista aposentado, que, ao se comparar com colegas da faculdade, afirma-se como um "burocrata alemão" em função da educação racionalizadora e austera que recebeu de seu pai, ou de Rafael, entrevistado que afirma ter encarado a entrada no ES e na UFSC enquanto um "caminho natural", ainda que seus pais não houvessem ultrapassado o EM (Ensino Médio) em suas próprias trajetórias escolares.

Conforme argumentaremos, esses perfis parecem ilustrar uma experiência própria às camadas sociais que Bourdieu designava como "pequena burguesia” (2007), orientada pela racionalização dos modestos volumes de capital econômico e cultural - por parte dos agenciamentos de socialização dos pais - que tendem, desse modo, a ser incorporados pela "boa vontade cultural" dos filhos, isto é, pela disposição subjetiva a investimentos educacionais que, de fato, os levam a ir mais longe do que os pais nos estudos.

Tal perfil contrasta com os casos dos últimos entrevistados que mencionaremos, cujos pais não possuem o nível médio de ensino, tendo ocupaçóes manuais de baixa qualificaçáo e se inscrevendo, com efeito, como 'casos excepcionais' de esforço e sucesso escolar em seu meio social e familiar. Esse é o caso, por exemplo, de Gabriela, pais com EF (Ensino Fundamental) incompleto (pai pedreiro, mãe "vendedora" sem maior especificação), criada em um bairro rural da cidade de Araranguá (sul do estado) e que conseguiu uma bolsa parcial para estudar em um colégio particular durante os dois últimos anos do Ensino Médio (EM), tendo ainda que trabalhar para pagar a mensalidade reduzida da escola.

7 Todos os nomes citados na pesquisa são fictícios, a fim de manter o anonimato dos colaboradores da pesquisa. 


\section{Familiaridade e naturalização da entrada no ES e na UFSC}

Os pais de Joana têm ES completo. O pai formou-se em Licenciatura/Química em uma instituição privada, ingressando (após trajetória ocupacional que sintetizaremos à frente) na carreira de Letras/Italiano da UFSC e percorrendo, então, seus estudos acadêmicos até o pós-doutorado na instituição. Sua mãe formou-se em Letras/Inglês, sem especificação da instituição ao longo da entrevista.

Ambos foram professores da educação básica na rede pública e militantes do Partido dos Trabalhadores (PT), tendo trabalhado tanto na burocracia quanto em administraçóes municipais ligadas ao partido.

Embora a adolescência de Joana tenha sido vivenciada em Araranguá (sul do estado), onde estudou em escola confessional privada, ela morou durante a infância em Florianópolis em bairros próximos à UFSC. Mesmo após a mudança para Araranguá, seu pai continuou a morar na capital, tendo a família mantido o laço com a cidade e os arredores da universidade.

É a partir dessa experiência biográfica que a entrevistada estiliza, portanto, sua proximidade familiar e residencial com a universidade, enxergando aí e na "profecia" (termo do autor) dos pais, seu futuro socialmente "incrustado" como estudante da instituição. Ela afirma não ter sequer "cogitado" estudar em outra instituição, ainda que, logo em seguida, relate ter se inscrito para o vestibular da Universidade do Estado de Santa Catarina (UDESC):

[...] como eu me criei aqui, na Trindade, minha infância eu ia andar de bicicleta na UFSC

[...]. Meus pais tinham amigos da UFSC e tal [...] E eu morava aqui na Serrinha, ou seja, a vida universitária fez parte muito da minha vida assim. Mesmo quando eu fui pra Araranguá, meu pai continuou por aqui. Então [...] já nasci com meus pais falando: "Ah! Quando você for fazer UFSC, assim, assim, assado [...]". Então, meio que tava incrustado em mim! Eu nem cogitei outras universidades. Eu só fiz UFSC [...]. Eu até me inscrevi pra fazer design industrial na UDESC, mas eu [...] não fu. Não fiz, e [...]. Fiz os dois vestibulares pra UFSC. Não fiz nenhum em particular.

O sentimento de proximidade física (morar perto; frequentar o campus), bem como a proximidade relacional (amigos dos pais que eram estudantes da instituição; ter experienciado algo da "vida universitária" já na infância) parece ter se conjugado ao capital cultural dos pais (ambos com 
ES, professores e militantes) para criar um meio de socialização em que a garota vislumbrava o destino de estudante universitária em uma instituição federal como algo "incrustado" em sua experiência pessoal, fazendo questão de afirmar, ao fim da fala, não ter tentado vestibular em nenhuma instituição privada.

Tal narrativa é adensada pelo enorme entusiasmo que o pai demonstra com relação à UFSC até os dias de hoje, uma vez que ele ingressou na UFSC como estudante de Letras, após sua trajetória ocupacional, percorrendo, então, todo o trajeto acadêmico até o pós-doutorado. Joana reporta divertidamente que seu pai tenta convencê-la a voltar à UFSC para um mestrado. A entrevistada náo descarta tal possibilidade para seu futuro, afirmando, porém, que estava, no momento da entrevista, centrada em construir uma "carreira", ao lado do marido com quem abriu uma empresa de móveis e decoração doméstica.

Essa transmissão de capital cultural, sacramentada pela escolarização básica em instituições privadas e caracterizada pela proximidade residencial e afetiva com a UFSC - decisivamente enfatizada pela entrevistada, como vimos - é paralela, no entanto, ao fato de que as Ciências Sociais não foram a primeira escolha de carreira da entrevistada. Inicialmente, ela presta o vestibular para o curso de Arquitetura, afirmando ter ficado muito próxima de uma vaga, frustrada, entretanto, pela alta concorrência pelo curso naquele ano específico.

Joana afirma ter então reajustado suas expectativas de escolha de curso, prestando o segundo exame para a carreira de CS. Ao ser indagada acerca das razóes da mudança, a entrevistada reporta: "Ah! Talvez eu tenha ficado com medo de me frustrar de novo, não passar por muito pouco e ficar mais um ano parada [...]".

Bourdieu e Passeron (1964) afirmavam que a escolha de carreiras menos prestigiadas frequentemente irrompe, em trajetórias sociais e educacionais, como um reajuste entre expectativas subjetivas e condiçóes objetivas de seleção e acesso a essa carreira.

Como veremos, este é um movimento recorrente entre os entrevistados e as entrevistadas que relatam, frequentemente, ter escolhido e tentado 
previamente carreiras mais prestigiadas, tendo posteriormente reajustado suas escolhas em direção à carreira de CS, mediante uma experiência de insucesso nos exames de seleção para as carreiras inicialmente pretendidas.

No caso de Joana, como veremos adiante, a garota justifica esse reajuste não somente a partir da influência política e militante de seus pais, como também como uma 'libertação' frente ao ambiente provinciano e socialmente conservador em que a entrevistada havia crescido durante sua adolescência em Araranguá.

Ao longo do texto, poderemos notar como a escolha da carreira em CS é frequentemente narrada nos termos de uma 'autonomização' ou de um 'desafio' ao ambiente provinciano e conservador de suas cidades de origem entre os entrevistados e as entrevistadas que migram do interior à capital catarinense para efetivar sua condição de estudante universitário na carreira de CS.

Dessa maneira, o curso de CS na UFSC é visto como um ambiente e uma experiência de diversidade e cosmopolitismo intelectual e social, uma abertura para evitar uma "cabeça bem menorzinha", segundo expressa Joana em seu relato, por exemplo.

A mudança de visão política de mundo (menos enfatizada no relato de Joana em virtude, possivelmente, da história militante dos pais) também adensará essa temática nos relatos seguintes de entrevistados. É a partir, pois, dessa abertura à diversidade social, intelectual e política que os entrevistados (Joana, inclusive) buscam justificar e expressar - como veremos no segundo tópico do texto - os sentidos e as razóes de cursar a carreira de CS a despeito das limitaçóes de inserçáo profissional que ocupam, previsivelmente, parte relevante da atenção e dos relatos dos entrevistados.

Joana personifica, em nossa amostra de entrevistados, portanto, a familiaridade e a naturalização da transmissão de capital cultural, a partir de dois pais diplomados no ES e da proximidade residencial e afetiva que experienciou com a UFSC desde a infância. Como veremos a seguir, esse perfil de experiência social e cultural já demarca alguma distância com relaçáo às experiências e trajetórias "pequeno-burguesa" dos entrevistados e das entrevistadas mencionados. Ambos os perfis contrastam-se com mais 
força, no entanto, ao último perfil de entrevistadas, caracterizadas como "casos excepcionais" de sucesso escolar em meios populares.

\section{A primeira geração de famílias "pequeno-burguesas" no ES e na carreira de CS na UFSC}

Tratando das camadas sociais interpostas entre a burguesia cultural ou econômica e as camadas populares - estrato social que, em termos correntes, costumamos designar como "classe média baixa" no Brasil - Bourdieu (2007) afirmava que a experiência social da "pequena burguesia” era orquestrada pela disposição subjetiva à racionalização de modestos volumes de capital econômico e cultural com o intuito de projetar nos filhos dessas famílias as possibilidades, materiais e simbólicas, de ultrapassar as restriçôes à ascensão social limitada de seus pais.

Bourdieu nota que tais disposiçóes ascéticas expressavam-se já no controle racionalizado da fecundidade familiar, desdobrando-se, frequentemente, em investimentos educacionais tendencialmente apropriados pelos filhos dessas camadas sob a forma da "boa vontade cultural", isto é, sob forma da adesão ativa aos valores, às práticas e ao mundo da escola.

Tal classe de agenciamentos e de disposiçóes são claramente reconhecíveis nas narrativas dos entrevistados e as entrevistadas que mencionamos nesse tópico.

Dessa maneira, podemos começar por um breve relato de Júlia (mãe, EF completo, dona de casa; pai, EM técnico, contador) que ilustra a "boa vontade cultural" projetada nos filhos a partir dos bloqueios e das frustraçóes interpostos à escolaridade dos pais.

A entrevistada expressa consciência acerca dos efeitos desse mecanismo de socialização que teria lhe inculcado uma concepção de educação formal ou "bancária", como ela própria afirma, aludindo, ironicamente, à noçáo formulada por Paulo Freire.

Eu acho que tinha todo assim uma crença, um idealismo em relação à escola, à coisa de formar, sabe? A escola formal assim, bancária, a educação bancária. Acho que tinha muito isso. E tinha um peso muito grande assim pra minha familia, até porque, tipo assim, a minha mãe não tinha terminado [a educação básica, foi até o fundamental], 
meu pai [...]. Então, acho que tinha isso e a gente acabava focando na escola mesmo, formal sabe?

Tiago (mãe, EF completo, dona de casa; pai EF completo, eletricista aposentado pela $\mathrm{CELESC}^{8}$ ) religa, por sua vez, a escolha racionalizada do momento em que seus pais o conceberam com seus planos e economias para assegurar a ele a escolarização privada durante o Ensino Básico para alcançar instituições públicas no ES. Caso o plano de acesso ao ES público (concebido antes mesmo de seu nascimento) "falhasse", os pais teriam feito, segundo ele, as economias necessárias para ajudá-lo a financiar o ES privado.

E[...] fui nascer só cinco anos depois do casamento [de seus pais], devido a esse planejamento financeiro, inclusive. Eu estudei em escola particular a vida inteira, justamente pra ter essa precaução de que eu pudesse entrar numa universidade federal, ou na UDESC. E ainda houve um planejamento também que, caso eu não passasse na federal ou na UDESC, ele [seu pai] pudesse custear uma universidade pra mim.

O investimento na escolarização privada durante a educação básica era secundado pelo disciplinamento, pela cobrança e pela vigilância do pai em relação à seriedade e aplicação do filho: disposição socializatória que o filho ligava à herança cultural germânica de seu pai, nascido em uma colônia de imigrantes alemães. Assim, o entrevistado expressa essa pressão paterna, sobre seu desempenho e comportamento escolar, a partir de termos tais como "terror psicológico" ou "chantagem" secundados pela ameaça parental de retirar o investimento na educação privada do filho?.

Seu pai ameaçava-o constantemente, portanto, com a perspectiva de matrícula na escola pública que, por uma dessas viradas irônicas (e comuns) em trajetórias biografias, acabou por ser o destino ocupacional de Tiago: o entrevistado é concursado e atua como professor de Sociologia na rede básica de Santa Catarina há quase dez anos.

Meu pai, nesse ponto, ele seguia aquela linha germânica de "eu te ofereço isso aqui, se vira em cima disso aqui". Eu não [...]. Tanto que ele [...] chegava aquele terror psicológico, que é [...].eu considerava assim "nossa, deve ser o fim do mundo" [estudar na escola pública], do jeito que ele relatava, que, depois quando eu comecei a trabalhar [trabalhar em uma escola pública], eu vi que não era, de "se tu rodar, tu vai pra escola pública". Então, havia essa chantagem bem forte, assim [...].

8 Empresa estatal de energia elétrica em Santa Catarina.

9 Conforme os entrevistadores relataram, essa entrevista foi emocionalmente tensa e "dificil" de ser conduzida. tendo havido momentos de pausa e de ocorrência de choro por parte do entrevistado. 
Ao se comparar com colegas de condiçôes supostamente mais privilegiadas na faculdade, Tiago afirma, com ironia (e, possivelmente, com algum exagero), que a austeridade ascética de seu estilo de vida e de suas possibilidades de gasto para a sociabilidade universitária (bares, festas etc.) o colocava como um "burocrata alemão" em comparação com os colegas mais propensos, objetiva e subjetivamente, ao hedonismo da vida e da sociabilidade na universidade.

Economias e sacrifícios familiares para investimento em escolarização privada durante a totalidade ou parte da educação básica é algo recorrente entre esses entrevistados e entrevistadas, que se aproximam do perfil "pequeno burguês". Seus pais, que não haviam acessado o ES, antecipam intuitivamente que a escolarização privada aumenta sobremaneira a chance de que seus filhos os superarem, do ponto de vista escolar, logrando acessar o ES.

Igualmente, esses pais compartilham com seus filhos as expectativas de que esse investimento possa prepará-los para o ingresso em uma instituição pública de ES, condição que libertaria os pais da continuidade dos sacrifícios, economias e agenciamentos para financiar a educação privada dos filhos após o EM.

Rafael (pai e mãe com EM completo; pai vendedor e mãe contadora em uma concessionária de veículos) estudou apenas um curto período em escolas públicas, tendo passado boa parte de sua escolarização em instituições privadas, assim como sua irmã mais velha, ingressante na carreira de Letras, na UFSC.

A partir da escolarização privada e do exemplo da irmã mais velha, o entrevistado afirma ter encarado o ingresso na UFSC como o "caminho natural" que o levaria não somente à universidade mas também à possibilidade de superar a estreiteza de possibilidades e de liberdades experienciada, junto à família, na cidade de Chapecó, oeste do estado de Santa Catarina, unindo-se à irmã mais velha já instalada na UFSC e em Florianópolis.

Antônio (pai, EF incompleto; mãe, ES completo, pedagoga que trabalha fora de sua área') afirma que sua mudança da escola pública para instituições privadas acompanhou a própria ascensão financeira dos pais, predispondo o entrevistado ao ingresso em uma instituição pública de ES. 
Por fim, Beatriz (mãe divorciada, EM incompleto, pequena empresária) é o último caso de entrevistada que comentaremos nesse perfil "pequeno burguês".

Ela afirma que a mãe a criou na condição de "uma classe média que se segura”. Em função do fato de a mãe ser pequena empresária, a entrevistada cita as flutuaçóes orçamentárias, ano a ano, e as dificuldades de não contar com um "salário fixo", para ilustrar os sacrifícios e a desenvoltura necessária para manter "carro" e "escola privada", isto é, os símbolos e estatutos de "classe média" que emergem no discurso e nas percepçóes dessa entrevistada.

Sua escolarização privada, durante todo o Ensino Básico, ocorreu em estabelecimentos confessionais reputados como instituiçóes de ensino tradicionais e elitizadas na cidade de Florianópolis. A entrevistada afirma que essas escolas estariam claramente acima das possibilidades financeiras de sua família, tendo sido mantidas, ainda assim, a partir do esforço e dos sacrifícios maternos. Beatriz tematiza, inclusive, que tais diferenças sociais entre ela e a clientela desses estabelecimentos de ensino modulava sua própria rede de sociabilidade junto aos colegas de escola, rede que excluía, portanto, a sociabilidade com os filhos de filhas de famílias mais tradicionais e elitizadas que estudavam no colégio ${ }^{10}$.

Não obstante, é essa escolarização de elite que predispõe a entrevistada a encarar como natural a passagem ao ES, ainda que ela tenha sido a primeira geração de sua família ao fazê-lo. A própria entrevistada expressa clara consciência sobre tal fato em sua fala. Como vemos abaixo, sua dúvida ou hesitação nunca foi entre ingressar ou não no ES, mas sim qual carreira escolher.

Ir pra universidade[...]. Nunca foi uma opção não ir. 0 que agora, olhando em retrospecto, é interessante, tendo em vista eu sendo a primeira pessoa da minha familia a ir pra faculdade; mas, era uma coisa óbvia. No entorno que eu tava, a escola que eu tava, nenhum dos meus colegas não ia fazer vestibular, então a escolha era

10 Tiago e Joana também tematizam como suas sociabilidades nas escolas privadas eram moduladas por desigualdades socioeconômicas entre eles e parte de seus colegas: consequência colateral dos sacrifícios parentais para financiar a educação dos filhos em escolas privadas bem reputadas. 
qual curso você ia fazer. Mas não ir à universidade não era uma opção, nunca foi, desde sempre, praticamente. Eu lembro, desde pequena, a ser incentivada a pensar o que você vai ser. Sempre eram coisas que requereriam você ir à universidade, $e$ isso vai ficando cada vez mais forte depois na escola, no Ensino Médio, que era totalmente voltado para o vestibular. No terceiro ano, a gente tinha aula de manhã, tinha aulas extras à noite só de preparação para o vestibular, tinha aula aos sábados. Então, tudo era voltado realmente para o vestibular, simulados e toda essa coisa. Então, a questão era só que curso você iria fazer, e não se você ia ou não fazer. Nunca foi, nunca pensei em não ir à faculdade, de jeito nenhum.

Com todos esses investimentos e sacrifícios parentais, sacramentados pelo acesso à educação privada, podemos nos perguntar como se dariam as eventuais tensóes entre a escolha da carreira de CS, por parte dos entrevistados, e as disposiçóes à ascensão social ou, ao menos, à estabilidade material por parte de suas famílias.

Então, como pais lidam com a escolha de seus filhos por uma carreira de perspectivas limitadas e incertas de inserção ocupacional, após tantos sacrifícios e investimentos?

Para tratar de tal questão, vale observar que, a exemplo do que havíamos visto no caso de Joana, também foi comum, entre os entrevistados mencionados nesse tópico, a escolha de CS como um reajuste de expectativas após o fracasso na tentativa efetiva de acessar uma carreira de maior prestígio ou após a mera "consideração" da hipótese (não empreendida ou tentada, entretanto) de seguir alguma dessas carreiras.

Tiago afirma, por exemplo, que considerou durante boa parte da adolescência cursar Engenharia Mecânica, tendo, entretanto, desistido da carreira por ter "travado" em Matemática no EM. Considerou, posteriormente, a carreira de Relaçóes Internacionais que, no entanto, ainda não existia na UFSC no momento em que ele prestou vestibular.

Rafael também afirmou ter considerado Engenharia Química (em função de um "tio rico", que tinha a mesma formaçáo), mas depois relata ter gostado da ideia de trabalhar em uma escola. Beatriz tentou efetivamente, por sua vez, a entrada na carreira de Jornalismo na UFSC. Após não ter passado, porém, ingressou em Relaçôes Internacionais em uma instituição privada e em CS na UFSC. 
Nesses recorrentes casos de reajuste de escolha de curso em direção à CS, são frequentemente narradas inseguranças e dúvidas dos próprios entrevistados e de suas famílias geradas pela escolha da carreira de CS.

Não obstante, é curioso notar que, nesses momentos e relatos, não foram narradas, em nossa amostra, intervençóes parentais no sentido de encorajar e financiar mais um ou dois anos de estudos, por meio de cursinhos pré-vestibulares privados, para que esses estudantes possam tentar novamente, o ingresso nas carreiras mais valoradas e escolhidas primeiramente.

Ou seja, não encontramos em nossa amostra o agenciamento próprio às famílias de classe média alta que tomam parte ativa no financiamento e no encorajamento da preparação pós-EM, paga e privada, para que esses jovens consigam ingressar nos cursos mais concorridos de instituiçóes de ES bem reputadas no campo acadêmico.

Desse modo, pois, parece razoável propormos a hipótese de que famílias aparentadas à "pequena burguesia", no léxico bourdiesiano, ou à "classe média baixa”, em termos mais correntes, teriam menor propensão a conceber e a apoiar esse tempo adicional de educação e de preparaçáo para o vestibular, tornando seus filhos e filhas mais suscetíveis, portanto, a reajustes de expectativas direcionados a carreiras menos concorridas.

Mas, obviamente, também é necessário notar que essas ocorrências de reajuste de carreiras não são as únicas vias de interesse ou de acesso ao curso de CS que aparecem em nosso material de entrevistas, pois, nosso material também apresenta trajetórias e dinâmicas de escolha de curso reveladoras de interesses culturais e políticos suscitados por redes de relaçóes mais singulares e particularmente importantes para a experiência social dos entrevistados.

O entrevistado Antônio afirma, por exemplo, que seu interesse por CS e, posteriormente, por Agronomia (ele ingressa nessa carreira após a conclusão da licenciatura em CS), emergiu a partir da amizade e da sociabilidade que teve com o pai de uma ex-namorada, sociólogo e agrônomo, que indicou e emprestou-lhe muitos livros de sociologia.

Paulo (pai, EM completo, bancário; mãe, ES completo, enfermeira) relata ter tido uma forte socialização religiosa em seu meio familiar, tendo 
se interessado pelo curso de Antropologia da UFSC (e, por consequência, pela licenciatura em CS) após ter lido o livro de um professor do curso sobre um dos cultos religiosos praticados pelo entrevistado.

Carlos (máe e pai com baixa escolaridade; criado pela avô e tia-avô, aposentada como funcionária pública) afirma, por sua vez, ter se interessado por CS a partir de sua militância política na adolescência (que define como "punk" e "anarquista"). A escolha do curso motivara-se, portanto, em função da expectativa de "entender e mudar a sociedade": "idealismo" e "romantismo" rompidos pelo curso, segundo o entrevistado afirma, e metamorfoseado, em sua trajetória de vida, pela militância dentro do "Estado de Direito", como o veremos afirmar posteriormente no texto.

\section{Casos "excepcionais" de sucesso escolar nas camadas populares: a entrada no ES e na carreira de CS na UFSC}

Bourdieu (2001) também designou, ao longo de sua obra, a figura dos "sobreviventes da superseleção escolar", isto é, jovens originados de camadas populares (pais com baixa escolaridade em ocupaçóes manuais pouco qualificadas, no campo ou na cidade) que, no entanto, demonstravam aptidóes e esforços escolares capazes de superar os subsequentes filtros socioculturais que o sistema de ensino aplicava sobre eles, logrando escapar, desse modo, da tendência de "autoexclusão escolar", que reproduz os baixos níveis de escolaridade de agentes originados dessas camadas sociais desprivilegiadas.

Lahire (1998) dedicou-se, por sua vez, a evidenciar configuraçôes familiares singulares caracterizadas por mecanismos de socialização capazes de dotar crianças do meio popular de aptidóes e competências que as levam ao sucesso escolar excepcional. Já a literatura brasileira sobre o acesso de jovens ao ensino superior (VIANA, 1998; SILVA, 2003) evidenciou como as disposiçôes para aliar o investimento duplo nos estudos e no trabalho constituem-se, comumente, nos esteios e nas alavancas a partir das quais uma minoria de jovens de meios populares logram alcançar os níveis mais altos do sistema de ensino.

Essas condições e agenciamentos de socialização são visíveis nos casos das duas últimas entrevistadas mencionadas. 
Gabriela é uma delas. Filha de mãe e pai com EF incompleto, mãe vendedora, pai pedreiro autônomo, a entrevistada foi criada, durante boa parte da infância, pelos avós (devido às rotinas extensas de trabalho dos pais), tendo estudado em escolas públicas, e trabalhado em bicos e atividades esparsas desde os 12 anos de idade.

Contudo, em um dado momento de sua trajetória, mudanças de horizonte e de possibilidades de escolarização passam a se acumular por força, conforme padrão já evidenciado pela literatura (VIANA, 1998, p. 6; BONALDI, 2015), de intervençôes de um ou mais agentes da instituição escolar que atuam no sentido de convencer os pais da garota da aptidão e da competência escolar "acima da média" possuído por sua filha.

Além da comunicação de vereditos escolares destacadamente positivos, tais agentes buscam amparar esses pais e estudantes na busca de oportunidades escolares melhores, fora das opçóes imediatas dos bairros em que moram essas famílias. Aqui, o sacrifício parental também é imprescindível, ocorrendo, como veremos no caso da entrevistada, para viabilizar a própria condiçáo de transporte da estudante à escola pública localizada no centro da cidade: assim, a máe de Gabriela dava a ela, como vemos abaixo, seu vale-transporte do trabalho, passando a ir trabalhar de bicicleta.

E ali [a partir da $4^{a}$ série do EF] já tive um incentivo de professores da escola municipal, de falarem com a minha mãe de me incentivar a estudar, a estudar em outra escola fora do bairro [...]. Então, eu lembro da diretora, porque é tudo muito próximo ali. É um bairro e todo mundo se conhece. Eu lembro da diretora falando que eu era muito aplicada e "blábláblá" e que seria interessante me levar para uma outra escola $e$ que eu pudesse tá em contato com outros colegas que fosse pra além do meu bairro. Eu lembro da diretora falando isso com a minha mãe. E, como a minha trabalhava no centro [da cidade], ela conseguia me ajudar a ir e voltar. Eu lembro que eu usava o passe dela pra ir pra escola. Ela ia de bicicleta e eu ia de ônibus com o transporte dela.

Após essa mudança para uma escola pública no centro da cidade, Gabriela obteve, já nos últimos dois anos do EM, uma bolsa parcial de estudos em um colégio privado. A contrapartida para a bolsa parcial era o trabalho, no contraturno escolar durante duas tardes da semana, na biblioteca do colégio. Mesmo com a bolsa parcial, a entrevistada relata a dificuldade para o pagamento das mensalidades. De fato, após a conclusão 
do EM, ela começou a trabalhar como caixa em uma grande rede de varejo de eletrodomésticos para poder quitar as contas com a escola e ter acesso ao seu diploma.

Tendo prestado vestibular para a carreira de Comunicação e Expressão Visual, na UFSC, e Design Gráfico na UDESC, a entrevistada não obteve sucesso nessa primeira tentativa, continuando a trabalhar na rede de varejos e a se preparar para a segunda tentativa, quando escolheu, então, a carreira de CS na UFSC e obteve a aprovação.

Tal reajuste de expectativas de curso processou-se, segundo seu relato, a partir do fato de que, quando adolescente, costumava acompanhar programas da TV Escola" e que se recordava de entrevistas com sociólogos e antropólogos sobre temas como classes sociais, Estado e questão ambiental ou indígena. Após a graduação, Gabriela foi aprovada em concurso para um Instituto Federal, tendo realizado o mestrado posteriormente e participando de uma seleçáo para doutorado no momento da entrevista.

Processos e condições assemelhadas são observados no relato de Luísa (pai, balconista, que "não quis saber muito de estudo", segundo a entrevistada; mãe, sem informação sobre escolaridade, costureira e esteticista).

A entrevistada foi alfabetizada antes de ingressar na escola, por iniciativa voluntária de uma vizinha formada em Pedagogia. Ao ingressar na escola, seu desempenho rapidamente impressionou a professora que lhe sugeriu "pular de série", oferta, entretanto, negada pela criança. Durante o EM, a entrevistada também obteve uma bolsa parcial em um estabelecimento privado e confessional, não tendo, entretanto, que trabalhar, ao contrário do que vimos no caso de Gabriela.

O caso dessa entrevistada revela-se, contudo, como um perfil de transição entre um caso de sucesso excepcional em camadas populares e os casos aproximados à condição pequeno-burguesa que vimos anteriormente.

Durante sua adolescência (ou seja, ao longo dos anos 2000), Luísa afirma que a família passa por uma sensível melhoria de suas condiçóes

II Ela afirma que, na casa de sua familia, na zona rural de Araranguá (sul do estado), esse era um dos canais e programas acessiveis a partir da antena parabólica que possuíam. 
econômicas, desdobrada, no momento em que a entrevistada obtém a bolsa parcial para o EM privado, em uma sequência de investimentos familiares em sua educaçáo que tomam lugar a partir de então: Luísa relata gastos de até $\mathrm{R} \$ 1.400,00$ em livros e material didático na escola privada que ela passa a frequentar no EM, faz um cursinho pré-vestibular e também passa a cursar Inglês durante a faculdade. Pouco tempo após sua graduação, a entrevista foi aprovada em um concurso para professora da rede pública de educação básica: ocupação que desempenhava no momento da entrevista.

\section{Experiências e sentidos vivenciados durante a licenciatura em CS na UFSC}

Uma fronteira que separa claramente diferentes formas de vivência e de fruição da experiência universitária é, reconhecidamente, a necessidade ou não de trabalhar durante a graduação como, aliás, a literatura sobre a figura dos "estudantes trabalhadores" evidencia (Romanelli, 2003).

Júlia, a entrevistada que nos proveu a fala a partir da qual discutimos a noção bourdiesiana de "boa vontade cultural" (definidora da experiência educacional da pequena-burguesia), sente a necessidade de expressar seu arrependimento e, aparentemente, até mesmo de se desculpar, quando os entrevistadores lhe perguntam sobre seu envolvimento em atividades ou em experiências extraclasse (tais como o engajamento em movimento estudantil e/ou em núcleos de pesquisa) durante o curso.

Olha, pra ser bem honesta, não. Eu me preocupava mais em trabalhar e estudar assim, porque realmente eu senti o peso de que, se eu perdesse o emprego, eu não tinha como continuar. Sabe, estudando[...]. Eu precisava. E não é só isso. Talvez seja um pouco [...] eu esteja querendo me desculpar assim. Eu realmente, eu fiquei meio alheia a isso. Acho que eu poderia ter me envolvido mais, sabe?, com movimentos sociais, sabe? Acho que eu poderia. Eu tava tão naquela redoma, naquela coisa "olha, eu tenho que trabalhar, tenho que fazer tudo certo. Eu não posso perder o meu emprego. Eu tenho que tirar boas notas, eu tenho que ter uma boa performance acadêmica". Nem sei pra que, mas eu achava isso. Entendeu? Tipo assim: fica aquela coisa meio perfeccionista de querer fazer tudo certinho, e tá tudo se enquadrando, se encaixando. Eu acho que eu perdi esse fio da meada assim, sabe? [e Tá ali, essa coisa do grupo de pesquisa, que eu acho super legal, que eu acho que faz uma diferença, né?, na vida acadêmica. As discussões, né? E o trabalho. Eu acho que isso foi uma coisa que eu perdi o timing sabe. Eé uma coisa que eu me arrependo assim, sinceramente. Eu acho que foi, eu poderia ter me envolvido mais ao invés de ficar tão preocupada com as questões institucionais e formais, ne? Nesse sentido assim. 
Já Gabriela, a entrevistada que personifica o sucesso excepcional em camadas populares e que ingressa no curso trabalhando como caixa de uma rede nacional de varejo, relata que a condição dupla de "trabalhadora e estudante" terminou por vitimar sua autoimagem de "boa aluna" quando passou a receber notas ruins em disciplinas das quais gostava. Foi a partir de tal experiência que a entrevistada decidiu pedir demissão do emprego em tempo integral, passando a garimpar auxílios de permanência e bolsas de estágios na universidade, apertando ao máximo seus gastos e contas para, dessa maneira, poder seguir o curso sem a necessidade de trabalhar em tempo integral e fora da universidade.

No caso oposto de Beatriz que, a partir dos sacrifícios maternos, frequentou um estabelecimento confessional de elite em Florianópolis, ingressando em CS na UFSC e em Relaçóes Internacionais (RI) em uma instituição privada, a extensão da moratória com relação ao trabalho, durante o ES, dotou a entrevistada das condiçôes de participar de diferentes experiências e atividades extraclasse nessas duas graduaçóes simultâneas que ela realizou.

Assim, Beatriz integrou a empresa júnior e o centro acadêmico de seu curso de RI e teve bolsa de iniciação científica e participação em núcleos de pesquisa da UFSC. Provavelmente, não é coincidência o fato de que a entrevistada relata ter começado a pensar e a planejar seu mestrado logo na metade de sua graduação, tentando, inclusive, se informar e antecipar possibilidades de estudar fora do país ${ }^{12}$.

Nesse sentido, portanto, é possível entender como condições materiais e culturais de socialização familiar continuam a modular os sentidos e experiências vivenciados distintamente, ao longo do curso, por diferentes entrevistados e entrevistadas.

Institucionalmente, é verdade que todos devem cumprir a mesma grade de disciplinas ou volumes de créditos, tendo, supostamente, acesso indiferenciado a múltiplas atividades e oportunidades de atuação e de formação extraclasse. Do ponto de vista mais realista e prático, no entanto,

12 De fato, ela acabou tendo experiências de formação e de intercâmbio internacional tanto no mestrado quanto no doutorado, trabalhando, no momento da entrevista, em uma universidade norte-americana. 
os entrevistados tecem percursos e vivenciam experiências bem diferentes dentro do "mesmo" curso e da instituição.

Mas a sensibilidade inescapável a essas e a tantas outras diferenças entre os entrevistados náo deve nos impedir de abordar, igualmente, interessantes e surpreendentes recorrências e invariâncias que emergem nas temáticas e relatos de nossa amostra. Nesse sentido, devemos notar a ocorrência de, pelo menos, duas temáticas que despontam com uma recorrência impressionante entre entrevistados e entrevistadas originados de experiências sociais e familiares bem diferentes entre si.

Uma delas é a representação comum de que, a despeito das limitações de perspectivas profissionais oferecidas pela carreira, o curso de CS amplia horizontes de pensamento e de perspectivas sobre a realidade social, cultural ou política e que, ao fazê-lo, ele "melhoraria" os entrevistados enquanto "pessoas" ou "seres humanos", como é frequentemente relatado.

É a partir de tais representaçóes e narrativas que os entrevistados encontram, como veremos, um repertório intelectual, moral e político para justificarem os "ganhos não materiais" (expressão do autor) que a formação em CS pôde lhes oferecer, apresentando o ambiente acadêmico do curso e da UFSC como uma experiência de riqueza e de diversidade cultural e intelectual que teria marcado positivamente suas trajetórias.

A outra temática recorrente nas entrevistas é o encaminhamento pragmático dos entrevistados à licenciatura, ou melhor explicando, a decisão de cursá-la não exatamente como resultado de uma "vocação" pessoal à docência na Educação Básica, mas sim como um dos poucos recursos e oportunidades, encontrados durante o curso, que puderam conferir aos entrevistados um sentido mais prático associado à carreira de CS, bem como um horizonte menos incerto de profissionalização dentro dela. Não obstante, nos relatos, também é recorrente a emergência de algumas críticas à formação ofertada pela licenciatura a despeito do apelo atrativo que ela exerceu sobre os entrevistados.

A partir de agora, discutiremos, separadamente e em detalhe, essas temáticas recorrentemente notadas nos relatos. Começaremos tematizando os "ganhos não materiais" que os entrevistados associam à carreira de 
CS. Em seguida, no último tópico do texto, discutimos as representaçôes vigentes sobre a licenciatura entre os entrevistados.

\section{Os ganhos não materiais do curso de CS: a dimensão intelectual, ética e política da formação}

Ao ser perguntado sobre o que o curso de CS havia "trazido para sua vida” (segundo os termos empregados pelos entrevistadores), Tiago recordou animadamente a atmosfera e a diversidade do público universitário com quem passaria a conviver na UFSC, fato que o impressionara já no dia da matrícula.

Então, quando eu comecei a ver a grande diversidade que havia e também os professores, sendo estrangeiros alguns deles, como nós sabemos alguns, aquilo pra mim foi algo considerado mágico. Eu entrei superempolgado, eu [...] "poxa, é algo que eu realmente gostei, que eu me identifico, não tem grandes problemas até o momento". [...] Eu adorei ter entrado, quando eu [...] eu lembro até hoje quando eu peguei o ônibus para [...] do semidireto e desci ali na BU [biblioteca universitária] pra fazer a matrícula eu vi: "gente, o que é isso?!", como é que eu vou explicar [...] era uma imensidão de pessoas de vários é [...] portes, espécies, assim por diante, quando eu vinha de escola particular que não tinha uma grande diversidade de pessoas, basicamente falando, e aquilo eu considerei sensacional. Eu acabei fazendo um contato interessante com um sujeito que a gente começou a conversar e comentar de algumas pessoas que a gente ficou interessado, que olhava. Aquilo pra mim [...] eu achei o máximo, sensacional. Eu não tenho palauras pra descrever até hoje, foi uma experiência que eu já comecei a gostar a partir do momento em que eu fui fazer a minha matrícula.

Assim como outros entrevistados, Luísa expressou um relato semelhante, reportando como fora positivamente impactada, desde os primeiros dias de faculdade, com o "tamanho" da biblioteca, a diversidade de professores e alunos, a "bateria de aulas" longas e aprofundadas, bem como o almoço no Restaurante Universitário a apenas $\mathrm{R} \$ 1,50$.

Frequentemente, os entrevistados aprofundavam esses relatos, exprimindo o efeito global que a experiência acadêmica no curso de CS exerceu sobre dimensôes intelectuais, morais e políticas de suas visões de mundo.

É nesse sentido que Alessandra afirmará, por exemplo, que “hoje eu posso dizer que [o curso de] Ciências Sociais mudou o meu modo de ver o mundo, de eu enxergar as coisas, me mudou como pessoa". 
Tais relatos costumam ser enfatizados entre os entrevistados que migraram do interior para a capital catarinense, tornando-se estudantes do curso. Mesmo Joana, a entrevistada de transição mais familiar e naturalizada à UFSC, como vimos, expressa, nesse sentido, um relato sobre oposiçóes significativas entre a cidade em que morava e o ambiente social e intelectual que encontrou no curso.

[...] fiz as ciências sociais e foi um curso maravilhoso. Ao meu ver, pra mim como pessoa em desenvolvimento de ser humano [...] Araranguá é uma cidade pequena então, às vezes, tu entra numa [...] numa caixinha meio limitada, né? E aí eu, por ter feito [...] sido formada no colégio com essa [...] com esse perfil, né?, de cidade pequena, colégio particular, sem muito estímulo, sem aula de Sociologia e Filosofia, porque [...].

Rafael repetiria Joana ao comentar as oposiçóes entre sua rede de sociabilidade em Chapecó e em Florianópolis após a migração e o início do curso.

Comumente, os entrevistados realizam espontaneamente exercícios, expressos em linguagem irônica, sobre como eles seriam diferentes e teriam outras visões de mundo caso não houvessem cursado a formação em CS. Notemos que esses exercícios especulativos apresentam explicitamente esses "ganhos não materiais" (isto é, aquisiçôes de natureza intelectual, ética ou política) como compensadores para as limitaçóes financeiras ou profissionais experienciadas após a graduação. Ou seja, é a partir dessa linguagem e dessa representação, sobre os "ganhos não materiais" da formação em CS, que os entrevistados encontram um repertório para racionalizar e justificar sua passagem no curso, negando quaisquer questionamentos de sua escolha.

Não obstante, é impossível perder de vista o fato metodológico de que a própria situação de entrevista proposta pela pesquisa (ou seja, uma entrevista realizada por estudantes de graduação e pós-graduação na própria carreira de CS) apresenta-se como uma interação social que, obviamente, incita esses tipos de racionalização positiva do curso por parte dos entrevistados. Voltaremos a discutir esse relevante fato metodológico ao final do tópico.

Após salientar as diferenças entre si e suas amigas de colégio em Araranguá (a "burguesia da escola", todas casadas e grávidas no momento 
da entrevista, segundo a entrevistada), Joana oferece, por exemplo, um relato significativo sobre o que ela teria perdido e ganhado ao náo persistir no caminho possivelmente "mais lucrativo" da primeira carreira que havia escolhido, ou seja, a Arquitetura.

Ou seja, eu podia ter seguido esse caminho né? Teria sido bem mais lucrativo! [referindo-se à carreira de Arquitetura] [risos]. Mas eu teria sido uma pessoa bem mais idiota, porque [...] criada numa cidade menorzinha, eu tava com uma cabeça bem menorzinha. E ai as ciências sociais me abriram pra um pensamento que eu acho que é fundamental, e que eu poderia ter ficado sem isso e me tornado uma pessoa muito mais [...] não sei né [...] "um 'se' não joga", com diz o meu pai [...], mas [...] uma pessoa muito menos esclarecida, podemos dizer assim [...].

Tiago também relata algo assemelhado ao enfatizar os "ganhos não materiais" que associa à formação em CS: “[...] realmente foi bom [ter feito o curso de CS]. Realmente foi bom, pra eu crescer mentalmente, intelectualmente; senáo, talvez eu seria só um serzinho medíocre qualquer, reacionário e que náo trouxesse alguma soma de virtude pra outras pessoas".

É interessante notar que, reiteradamente, as falas e os relatos transcritos mobilizam termos e frases que expressariam algo como um efeito "humanizador" da formação em CS. Basta retomar os relatos acima para vermos os entrevistados afirmarem que o curso promoveu neles mudanças "como pessoa", como "pessoa em desenvolvimento de ser humano" ou que, sem a formação em CS, eles imaginariam ser uma "pessoa muito menos esclarecida" ou um "serzinho medíocre qualquer, reacionário".

Se, por um lado, tal uso reiterado de termos um tanto quanto "holísticos" ou "humanizadores" (termos do autor) pode introduzir um "romantismo" algo exagerado ou caricato nos pontos de vista e nas visóes de mundo dos entrevistados; por outro, a exegese desses termos parece revelar a perspectiva crítica, implicitamente compartilhada pelos entrevistados, acerca da formação técnica e profissionalizante, presente em outras graduaçóes, que eles consideram ser, felizmente (adotando o ponto de vista dos próprios entrevistados), superada pelo curso de CS.

Tal digressão nos leva à questão, diretamente tematizada ao final do roteiro de entrevistas, sobre as mudanças de perspectivas políticas experienciadas pelos entrevistados durante o curso. 
Todos os entrevistados afirmaram que o curso teria impactado, de algum modo, sua visão política de mundo. A ampla maioria dos entrevistados afirma que, durante o curso, eles teriam experienciado uma conversão de um "senso comum" pouco ou nada crítico ante a realidade social, econômica e política para uma posição mais crítica que varia de uma "esquerda liberal" (Beatriz) ou "A la Bobbio, esquerda liberal [...] diferente do padrão do que os tucanos querem fazer" (Tiago) para posiçôes mais radicais: "comunista" (Luísa) ou "mais próximo" do "anarquismo" e do "ecossocialismo" (Paulo) ${ }^{13}$.

Como a ampla maioria dos entrevistados afirmavam ter se originado de meios sociais e familiares apolíticos ou conservadores, não possuindo contato anterior à universidade com militâncias ou posicionamentos políticos, a formação em CS era descrita como um período de mudança de perspectiva política em direção a alguma das posiçôes na gradação do centro à esquerda acima mencionada.

No caso único de Carlos, porém, engajado durante a adolescência em um ativismo "anarquista" e "punk", como ele descreve, tendo-se interessado pelo curso de CS para "entender" e "mudar" a sociedade, o curso havia, conforme ele relata, "quebrado idealismos e romantismos", convertendo-o a uma ideia de "militância dentro do Estado de Direito", como ele próprio afirma. Para a maioria dos entrevistados, portanto, a experiência no curso leva-os a algum ponto do espectro político, localizado entre o centro e a esquerda. Já no caso em que o entrevistado chega "radicalizado" ao curso; entretanto, a formaçáo em CS parece atuar em sentido inverso, moderando as posiçóes políticas desse entrevistado.

Por fim, cabe-nos discutir o fato metodológico, comum a estudos qualitativos, a que aludimos anteriormente. De que modos e em quais intensidades a própria situação social da entrevista pode condicionar pontos de vistas e narrativas expressos pelos entrevistados?

Conforme argumentamos na Introduçáo, a metodologia qualitativa discute longamente como a condução de observaçóes etnográficas ou de

13 A posição da entrevistada Júlia parece ser a única que escapava a essa gradação à esquerda do espectro político e ideológico: a entrevistada afirma não gostar de "rótulos", colocando em dúvida a existência definida de uma "direita" ou "esquerda". 
entrevistas em profundidade constituem-se, inevitavelmente, como encontros ou interaçóes sociais, nos quais os dois ou mais agentes em interação buscam - como tende a ocorrer, aliás, em qualquer outro tipo de encontro ou interação "face a face" (GOFFMAN, 2011) - controlar as representaçóes ou "impressóes" que eles geram nos demais agentes com quem interagem.

Ademais, também costuma haver, em encontros e interaçôes sociais, a tendência recorrente à modulação de falas ou de modos de se portar com o intuito "conveniente" ou "polido" de se evitar mal-estares ou rupturas brutas nas situaçóes interativas .

Sabidamente, em nossa experiência de pesquisa, as interaçóes sociais, que constituíam as situaçóes de entrevista, colocavam em diálogo licenciados em CS e estudantes (de graduação ou pós-graduação) da mesma área. Por um lado, em tais interaçóes, tendia a se estabelecer um acordo de cumplicidade e de confiança mútua entre entrevistado e entrevistadores que, como afirma Bourdieu (1997), pode se constituir como um laço relacional imediato que assegura aos entrevistados a confiança de que serão compreendidos em suas experiências e pontos de vista, uma vez que os entrevistadores comungam algo dessas experiências e pontos de vista. Tal proximidade relacional contribuiria, dessa maneira, para estimular a cooperação ativa e aprofundada dos entrevistados nessa situação de entrevista.

Por outro lado, no entanto, outra dinâmica relacional também se impóe. Afinal, ao se depararem com entrevistadores que são, com efeito, estudantes de graduação e de pós-graduação, engajados na formação em CS, é altamente provável e compreensível que os entrevistados tenham modulado, deliberadamente ou não, algumas de suas falas e pontos de vista, no sentido de contornar ou suavizar experiências ou narrativas mais "amargas" sobre o investimento subjetivo na carreira de CS. Tal tendência de contorno ou suavização de pontos de vista pode ocorrer como um agenciamento, deliberado ou não, para evitar quaisquer desencorajamentos aos jovens estudantes que conduzem a pesquisa, mantendo, ademais, a atmosfera leve e gentil que caracterizou praticamente todas as entrevistas (segundo os relatos dos entrevistadores).

Nesse sentido, tal exercício de reflexividade metodológica nos leva a ressalvar que a expressáo de alguns dos pontos de vista dos entrevistados 
(sobretudo acerca do que chamamos de ganhos "não materiais" da formaçáo em CS) pôde ter sido modulada, em algum grau, pelo próprio tipo de interação social que constituiu as situaçóes de entrevista.

Tal ressalva não equivale, entretanto, à invalidação nem dos pontos de vista expressos pelos entrevistados, nem de nossos esforços de interpretação do material de entrevistas, sobretudo nesse ponto específico dos ganhos "não materiais" da formação.

A questão sociológica elementar, que parece resistir à ressalva apresentada, continua a ser o fato de que, quando instados a racionalizar uma justificativa para si ou para terceiros sobre a validade, a legitimidade, os ganhos, as alegrias e felicidades de terem se investido durante tantos anos - de leituras, discussóes, provas e trabalhos etc. - na carreira de CS, a linguagem e o repertório que esses entrevistados recorrentemente encontram para formular e externar sua adesão subjetiva ao curso é, justamente, essa linguagem e o repertório dos ganhos "não materiais", ou seja, das dimensões intelectuais, morais e políticas que qualificam suas mudanças de visões de mundo e modos de agir e de pensar experienciadas ao longo do curso.

Mesmo no caso de Julia, uma entrevistada que tematizou longamente um doloroso processo de acomodação subjetiva às possibilidades objetivas de carreira, após ter se desiludido com a docência no Ensino Básico ("megassucateada”, segundo sua fala), podemos observar, em diversos momentos da entrevista, a expressão espontânea do gosto e da inclinação pelas CS, combinados à representação contínua, por parte da entrevistada, sobre as dimensôes intelectuais, culturais e políticas que a formação envolve.

No momento da entrevista, Julia relatava que, após algumas leituras, começara a considerar "o direito de não ter uma carreira", ou seja, a possibilidade de se dedicar, em bases regulares e cotidianas, a mais de uma área ou atividade de interesse e de trabalho: uma forma encontrada pela entrevistada, portanto, de reagir subjetivamente a impasses objetivamente experienciados por ela ${ }^{14}$.

14 Vale complementar que, no momento da entrevista, Júlia relatou estar estudando para concursos públicos, privilegiando concursos relacionados à área da Antropologia. 


\section{Licenciatura em CS: "encaminhamento pragmático" e sentidos da formação}

Como afirmado desde o início, a pesquisa acessou egressos da licenciatura em CS, completada ao longo dos anos 2000, por meio de uma lista fornecida pela Secretaria do Curso.

Havia entre os entrevistados uma variedade de situaçôes que compreendiam tanto egressos do curso que completaram tão somente a licenciatura, egressos que também tinham cursado o bacharelado ou, ainda, aqueles que declaravam estar cursando ou que ainda pretendiam cursar o itinerário do bacharelado após o término da licenciatura.

Em nosso curso, a entrada no bacharelado e na licenciatura dá-se através da concorrência no mesmo processo seletivo. A partir do quarto semestre, os estudantes podem, então, matricular-se em disciplinas específicas da licenciatura, do bacharelado ou, eventualmente, em disciplinas desses dois itinerários formativos.

Para obter a licenciatura, os estudantes precisam cumprir, além dos créditos compartilhados com o bacharelado, quatro disciplinas optativas e oito disciplinas obrigatórias somente à licenciatura ${ }^{15}$. Entre essas oito obrigatórias à licenciatura, duas são oferecidas pelo Departamento de Sociologia e Política ("Sociologia da Educação" e "Seminário de Licenciatura"), sendo as demais ofertadas pelos departamentos ligados ao Centro de Educação (CED) da UFSC e, no caso único da disciplina "Psicologia da Educação", pelo Departamento de Psicologia. Também se exigem dos estudantes a realização de dois estágios supervisionados e a apresentação de um Trabalho de Conclusão da Licenciatura (TCL).

Entre os 11 entrevistados, havia quatro professores concursados na rede pública de ensino na disciplina de Sociologia (Alessandra, Tiago, Luísa e Carlos), os entrevistados Júlia e Paulo que trabalharam como professores temporários na rede, mas que desistiram da ocupação, Roberta que aspirava se concursar como professora na rede e Gabriela, concursada em um instituto federal ${ }^{16}$.

15 São elas: Teoria da Educação, Didática e Psicologia da Educação, Sociologia da Educação, Metodologia do Ensino em Ciências Sociais, Organização Escolar, Estudos Afro-Brasileiros, Seminário de Licenciatura.

16 A outra metade da amostra seguiu outros caminhos ocupacionais, como é possível observar no Quadro do Anexo I. 
No material de entrevistas, é possível notar, primeiramente, que são raros os relatos em que a opção (exclusiva ou não) pela licenciatura é narrada como uma "escolha pessoal", motivada por uma eventual vocação sentida pela docência na Educação Básica. Tal constatação não causa surpresa quando consideramos o baixo prestígio conferido, infelizmente, à ocupação docente no país.

Nesse contexto, os entrevistados narram sua opção pela licenciatura como um encaminhamento de natureza mais pragmática do que propriamente vocacional. A licenciatura tende a ser vista, portanto, como o horizonte prático que oferta perspectivas mais seguras de profissionalização. Constatação que, como veremos, exerce mais atração sobre os entrevistados premidos, por condicionantes socioeconômicos, ao ingresso mais urgente no mercado de trabalho.

Dessa maneira, por exemplo, Alessandra é categórica ao afirmar que optou pela licenciatura em função da abertura do "mercado de trabalho" após a promulgação da lei que restituiu a obrigatoriedade da Sociologia e da Filosofia no EM em 2008. Carlos afirma, em sentido assemelhado, que a licenciatura "te dá um propósito, pegar o diploma de professor e dar aulas". Júlia também considerou que "dar aulas era um caminho mais natural" para quem está na carreira de CS, optando, portanto, pela licenciatura. Tiago faz a mesma escolha ironizando que "o 'paitrocínio' [isto é, o financiamento do pai] é finito" e que, dessa maneira, ele se sentia premido a ingressar no mercado de trabalho logo após a graduação.

Além desse "encaminhamento pragmático" (termo do autor) à licenciatura, os entrevistados expressam - diretamente, por vezes - que a formação na licenciatura teria, supostamente, uma "qualidade inferior" (como afirmam dois entrevistados) à formação no bacharelado, relatando casos em que colegas ou, até mesmo professores do curso, "brincam" com essa suposta desigualdade entre os dois itinerários formativos.

Como já foi discutido em diferentes contextos universitários, inclusive no nosso (STRESSER, 2018), uma hierarquia informal entre o estatuto do bacharelado e da licenciatura é produzida e reproduzida pelas categorias de percepção e por formas de sociabilidade no interior de cursos que ofertam as duas formaçóes. Nesse sentido, tal hierarquia entre licenciatura 
e bacharelado alimenta-se e é alimentada pela hierarquia estabelecida entre pesquisa e ensino, bem como entre a orientação para atuação no Ensino Superior ou no Ensino Básico.

Mas, além de notar essas relaçóes hierárquicas, os entrevistados mostraram grande interesse em nos ajudar com apontamentos e críticas construtivas às experiências que eles tiveram na licenciatura. Tal questão mobilizou, sobretudo, os quatro entrevistados (Alessandra, Tiago, Carlos e Luísa) que atuam na rede pública e que puderam comparar sua experiência formativa na licenciatura com suas experiências de trabalho. Experiências de trabalho que, em alguns casos, já somam quase uma década na lida com o ensino de sociologia no ensino médio.

De um lado, os entrevistados reconhecem que a licenciatura lhes ajudou com competências específicas (como "montar um plano de ensino", como afirma Tiago) ou com discussóes específicas abordadas nas disciplinas. Por outro lado, eles tematizaram, em geral, dois apontamentos críticos à formação no curso.

O primeiro deles é sintetizado por Alessandra ao afirmar seu desamparo, ao iniciar sua carreira docente, com a constatação de que a licenciatura não a havia preparado para, como ela afirma, o "chão da escola", ou seja, para ocorrências, dilemas e problemas cotidianos, também relatados por outros entrevistados, em termos de indisciplina, de desinteresse e, mais recentemente, de policiamento ideológico por parte dos estudantes ou de seus pais ${ }^{17}$.

Nesses momentos, alguns entrevistados colocam em questão o caráter excessivamente teórico da licenciatura, reconhecendo que tal caráter é balanceado, mas não suficientemente, talvez, pela experiência dos dois estágios supervisionados.

Outra questão comumente levantada pelos entrevistados é a existência de um grande descompasso - segundo suas próprias representaçóes - entre as disciplinas da licenciatura ofertadas por outros departamentos (são seis, ao total, como vimos) e a realidade e especificidade das ciências sociais. Os

17 Riscos e ocorrências efetivas de policiamento de caráter ideológico foram reiteradamente narrados pelos entrevistados que possuíam experiências docentes na educação básica. 
entrevistados afirmam existir poucas mediaçôes entre conteúdos abordados nessas disciplinas e os desafios, pedagógicos ou disciplinares em relação aos quais eles devem desenvolver e exercer estratégias cotidianamente.

Ainda que essa crítica quanto ao descompasso entre a especificidade do ensino de Sociologia e os conteúdos e temáticas de disciplinas ofertadas por outros departamentos seja de difícil reação ou resposta por parte de nosso departamento, acreditamos que as demais colaboraçôes e feedbacks apresentados pelos entrevistados podem nos encorajar a pensar em iniciativas e agenciamentos que pudessem tentar mitigar os problemas apontados em nossa licenciatura.

A título de sugestão, por exemplo, prover encontros e atividades regulares entre nossos licenciandos e professores da rede pública pode se configurar como uma oportunidade ímpar para a troca horizontal de ideias, experiências e conhecimentos, entre a universidade e as escolas, sobre possíveis estratégias, planos de aula ou abordagens relativas aos problemas cotidianos de indisciplina, de desinteresse ou aos riscos contemporâneos de policiamento de natureza ideológica, existentes atualmente no "chão da escola", como relatou Alessandra.

Pensar a carga horária de Práticas Pedagógicas como Componentes Curriculares (PPCCs) existentes em nossas disciplinas obrigatórias como oportunidade para treinos e exercícios efetivos de "transposição pedagógica”, ou seja, pensá-la como exercícios de conversão do conteúdo dessas disciplinas em materiais didáticos ou em planos de aula, elaborados em linguagem acessível e interessante a estudantes de EM, pode ser outra iniciativa interessante.

Por fim, tentar diversificar os contextos escolares em que os estágios supervisionados sejam realizados - evitando sua concentração no Colégio Aplicação da universidade, por exemplo - pode, igualmente, ser um esforço que aproxima os estudantes dos ambientes escolares que eles terão mais chances de encontrar em seu cotidiano profissional. Tudo isso mediado, é claro, pelos esforços e pela mobilização que serão necessários à manutenção da Sociologia e da Filosofia nas grades escolares. 


\section{Conclusão}

Este exercício de pesquisa qualitativa não busca reivindicar capacidade de generalização para suas eventuais conclusôes ou resultados ${ }^{18}$.

Como argumentamos na Introdução, nosso estudo tenta apreender e descrever, na verdade, as experiências e os pontos de vista dos entrevistados e das entrevistadas com o intuito de interpretar como esses agentes sociais expressam a interação entre diferentes condicionamentos socioeconômicos e culturais - indagados ao longo do roteiro de entrevista - em suas próprias experiências e trajetórias narradas.

É nesse sentido, portanto, que acompanhamos os entrevistados expressarem as suas experiências e os seus pontos de vista, articulando ambos com os condicionantes socioeconômicos indagados ao longo do roteiro de entrevistas, ou seja, a escolaridade e ocupação dos pais, as trajetórias escolares, as redes de relaçóes e de sociabilidade dos entrevistados etc.

Também vimos como a tematização dos "ganhos não materiais" da formação em CS, bem como os pontos de vista sobre a licenciatura, parecem apresentar certa autonomia relativa com relação às origens e trajetórias socioeconômicas. Isto é, eles tendem a ser tematizados de maneira recorrente entre os entrevistados: provável expressão, nesse sentido, do efeito socializador da experiência, compartilhada por todos entrevistados, de ter cursado CS na UFSC ao longo do mesmo período.

Em “A Miséria do Mundo", Bourdieu (1997, p. 704) fez o uso mais sistemático e refletido do recurso a entrevistas em profundidade, afirmando que a condução de uma entrevista em profundidade solicita, por parte do entrevistador, os maiores esforços possíveis para a suspensão temporária de seus próprios pontos de vista e categorias de percepção ("o esquecimento de si”), visando ao acionamento de uma "disposição acolhedora”. Uma disposição que inclinaria o pesquisador, portanto, a considerar e a experienciar, ainda que temporariamente, os problemas e os pontos de vista do entrevistado como se fossem seus próprios problemas e pontos de vista.

18 Capacidade essa que somente poderia ser reivindicada pelo emprego adicional de métodos quantitativos ou. eventualmente, pela acumulação indutiva de outros estudos qualitativos. 
Ao ativar tal "disposição acolhedora", nosso texto busca se inscrever como uma contribuição para que a diversidade de experiências, trajetórias e pontos de vista de estudantes de CS apresentada aqui - e, eventualmente, em contextos universitários semelhantes -, seja um pouco mais conhecida e clara aos leitores e leitoras do artigo, estimulando em nós, professores do ensino superior, o exercício contínuo de reflexividade ao ajustarmos e reajustarmos incessantemente as formas mais razoáveis de trabalharmos, de projetarmos nossas aulas, de organizarmos nossas relaçóes de orientação, de decidirmos os momentos e as formas de sermos mais exigentes com os estudantes, as ocorrências em que devemos ser mais lenientes etc.

Provavelmente, os próximos anos trarão muitos riscos e desafios à nossa comunidade acadêmica; logo, compreensão mútua e a disposição ao diálogo podem nos ajudar bastante.

\section{Referências}

ARENDEL, T. Reflections on the Researcher-Researched Relationship: A Woman Interviewing Men. Qualitative Sociology, v. 20, n. 3, p. 341-368, 1997.

BECKER, H. Métodos de Pesquisa em Ciências Sociais. 4. ed. São Paulo: Hucitec, 1999.

BONALDI, E. V. Sobre o "privilégio dos primogênitos" e as diferenças nas trajetórias educacionais de irmãos. Comunicaçáo apresentada na 37º Reuniáo Nacional da ANPED GT de Sociologia da Educaçáo, Florianópolis, 2015.

BOURDIEU, P. Espaço Social e Espaço Simbólico. In: Bourdieu, P. Razóes Práticas: sobre a teoria da ação. 9. ed. Campinas: Papirus, 1996. p. 13-33.

BOURDIEU, P. Compreender. In: Bourdieu, P. (Org.). Miséria do Mundo Petrópolis: Vozes, 1997. p. 693-713.

BOURDIEU, P. A "boa vontade cultural". In: Bourdieu, P. A Distinçáo: Crítica social do julgamento. São Paulo: Edusp, 2007. p. 298-350.

BOURDIEU, P. A escola conservadora: as desigualdades frente à escola e à cultura. In: NOGUEIRA, M. A.; CATANI, A. (Org.). Pierre Bourdieu - Escritos de Educação. 11. ed. Petrópolis: Vozes, 2011. p. 39-65.

BOURDIEU, P.; Passeron, J. C. Les Héritiers: les étudiants et la culture. Paris: Editions de Minuit, 1964.

GOFFMAN, E. Introdução. In: GOFFMAN, E. A representaçáo do eu na vida cotidiana. 18. ed. Petrópolis: Vozes, 2011. p. 11-24. 
LAHIRE, B. Sucesso escolar nos meios populares: as razões do improvável. São Paulo: Ática, 2008.

LUCHMANN, L. O Curso de Ciências Sociais na UFSC. Mosaico Social, Florianópolis, ano III, v. 1, n. 1, p. 7-68, 2002.

MALINOWSKI, B. Introduction. In: MALINOWSKI, B. Argonauts of the Western Pacific. Londres: Routleledge, 2002. p. 1-21.

MICK, J.; Diamanto, M.; Luz, J. R. O perfil do egresso do Curso de Ciências Sociais da UFSC (2000-2009). Mosaico Social, ano VI, n. 6, p. 347-386, 2012.

PIALOUX, M.; Beaud, S. Retorno à condição operária: investigação em fábricas da Peugeot na França São Paulo: Boitempo, 2009.

RIBEIRO, C.; Schlegel, R. Estratificação horizontal da educação superior no Brasil (1960-2010). In: ARRETCH, M. (Org.). Trajetórias das desigualdades: como o Brasil mudou nos últimos cinquenta anos. Sáo Paulo: Ed. Unesp, CEM 2015. p. 163-193.

ROMANELLI, G. Famílias de camadas médias e escolarização superior dos filhos: o estudantetrabalhador. In: NOGUEIRA, M. A.; ROMANELLI, G.; ZAGO, N. Família \& escola: trajetórias de escolarização em camadas médias e populares. 2. ed. Petrópolis: Vozes, 2003. p. 199-225.

SILVA, J. de S. Por que uns e náo outros? Caminhada de jovens pobres para a universidade. Rio de Janeiro: Sete Letras, 2003.

SMALL, M. 'How many cases do I need?' On science and the logic of case selection in fieldbased research Ethnography, v. 10, n. 1, p. 5-38, 2009.

STRESSER, C. Habilitaçáo em Licenciatura e Bacharelado em Ciências Sociais na Universidade Federal de Santa Catarina: interpretaçóes e sentidos das escolhas de itinerário formativo. Orientador: Prof. Dr. Eduardo Vilar Bonaldi. 2018. 83 f. Trabalho de Conclusão de Curso (Graduação em Ciências Sociais) - Centro de Filosofia e Humanidades, Universidade Federal de Santa Catarina, Florianópolis, 2018. Disponível em: https://repositorio.ufsc.br/handle /123456789/189225?fbclid=IwAR20XDuv8cfcO8DvxJKf-e7iOwZ01T_Fq0ryst_GOzn9oPRK3k76fOYPCw. Acesso em: 1 nov. 2018.

VIANA, M. J. B. Longevidade escolar em famílias de camadas populares: algumas condiçóes de possibilidades. Orientador: Maria Alice Lima Gomes Nogueira. 1998. 414 f. Tese (Doutorado em Educação) - Programa de Pós-Graduação em Educação, Universidade Federal de Minas Gerais, Belo Horizonte, 1998. 


\section{Social science undergrads at UFSC: Reflecting on (some of) their experiences, point of views and trajectories}

\section{Abtract}

This article aims at reconstructing the social, educational and academic trajectories of graduates in Social Sciences, at our university, from a material of twelve in-depth interviews with such graduates during 2000 s.

Firstly, we discuss the different dynamics and paths to 'choosing' the degree in Social Sciences among interviewees from different sociocultural backgrounds, considering, as the literature points out, both the "expectations readjustments" that can lead to careers of lesser social prestige, as well as the unique socialization experiences that inculcate, in some of our interviewees, specific propensities and interests towards our career.

Subsequently, we discuss some issues that were indistinctly thematized by interviewees from different sociocultural backgrounds, as, for instance, the theme of the "non-material gains" that interviewees routinely associate to their degree in Social Sciences despite the difficulties of professionalization frequently narrated by them.

Keywords: Socialization. Educational trajectories. Social Sciences. Teacher training.

\section{ANEXO}

TABELA DE ENTREVISTADOS

\begin{tabular}{l|l|l|l}
\hline $\begin{array}{l}\text { Pseudônimo, idade } \\
\text { e intervalo de anos } \\
\text { em que cursou CS }\end{array}$ & $\begin{array}{l}\text { Escolaridade e } \\
\text { ocupação dos pais }\end{array}$ & Onde fez EM? & $\begin{array}{l}\text { Destino após licenciatura } \\
\text { (ocupação e/ou outro } \\
\text { curso de graduação) }\end{array}$ \\
\hline $\begin{array}{l}\text { Julia, } 39 \text { anos, (2003- } \\
2008)\end{array}$ & $\begin{array}{l}\text { Pai: EM, técnico, } \\
\text { contador } \\
\text { Mãe: EF incompleto, } \\
\text { dona de casa }\end{array}$ & Escola pública & $\begin{array}{l}\text { Desistiu de ser professora } \\
\text { na rede pública, estuda para } \\
\text { concurso público na área de } \\
\text { Antropologia }\end{array}$ \\
\hline $\begin{array}{l}\text { Paulo, } 38 \text { anos, (2005- } \\
2010)\end{array}$ & $\begin{array}{l}\text { Pai: EM, bancário } \\
\text { Mãe: ES, enfermeira }\end{array}$ & $\begin{array}{l}\text { EM técnico, escola } \\
\text { pública }\end{array}$ & $\begin{array}{l}\text { Após quatro anos de } \\
\text { docência, desistiu de ser } \\
\text { professor da rede pública. }\end{array}$ \\
& & & $\begin{array}{l}\text { Assessor parlamentar e } \\
\text { professor de percussão e } \\
\text { ritmos do corpo. }\end{array}$ \\
\hline
\end{tabular}




\begin{tabular}{|c|c|c|c|}
\hline $\begin{array}{l}\text { Pseudônimo, idade } \\
\text { e intervalo de anos } \\
\text { em que cursou CS }\end{array}$ & $\begin{array}{l}\text { Escolaridade e } \\
\text { ocupação dos pais }\end{array}$ & Onde fez EM? & $\begin{array}{l}\text { Destino após licenciatura } \\
\text { (ocupação e/ou outro } \\
\text { curso de graduação) }\end{array}$ \\
\hline $\begin{array}{l}\text { Roberta, } 39 \text { anos, } \\
(2011-2016)\end{array}$ & $\begin{array}{l}\text { Mãe: EF incompleto, } \\
\text { doméstica, dona de } \\
\text { brechó e professora } \\
\text { de dança }\end{array}$ & $\begin{array}{l}\text { Escolas públicas } \\
\text { (fez um ano em } \\
\text { escola privada, } \\
\text { mas reprovou). }\end{array}$ & $\begin{array}{l}\text { Mestrado profissionalizante } \\
\text { para professores de } \\
\text { sociologia, UFPR. } \\
\text { Pretende se concursar como } \\
\text { professora na rede pública. }\end{array}$ \\
\hline $\begin{array}{l}\text { Carlos, } 31 \text { anos (2008- } \\
2014)\end{array}$ & $\begin{array}{l}\text { Pai: EF } \\
\text { completo(sem } \\
\text { informação sobre } \\
\text { ocupação), mãe } \\
\text { EM, por supletivo, } \\
\text { desempregada. } \\
\text { Foi criado pela avô e } \\
\text { tia-avô, essa última, } \\
\text { funcionária pública } \\
\text { aposentada. }\end{array}$ & $\begin{array}{l}\text { Parte no ensino } \\
\text { público, parte no } \\
\text { privado. }\end{array}$ & Professor de rede pública \\
\hline $\begin{array}{l}\text { Beatriz, } 35 \text { anos } \\
(2002-2006)\end{array}$ & $\begin{array}{l}\text { Mãe, EM incompleto, } \\
\text { pequena empresária } \\
\text { no ramo de } \\
\text { confecção }\end{array}$ & Escola privada & $\begin{array}{l}\text { Pesquisadora e curadora na } \\
\text { Universidade Católica da } \\
\text { América, Washington, EUA. }\end{array}$ \\
\hline $\begin{array}{l}\text { Antônio, } 30 \text { anos } \\
(2006-2011)\end{array}$ & $\begin{array}{l}\text { Pai, topógrafo, mãe, } \\
\text { ES, contadora }\end{array}$ & $\begin{array}{l}\text { Parte em escola } \\
\text { pública, parte em } \\
\text { escola privada }\end{array}$ & $\begin{array}{l}\text { Atualmente faz graduação } \\
\text { em Agronomia e estagia em } \\
\text { um projeto de extensão da } \\
\text { universidade. }\end{array}$ \\
\hline $\begin{array}{l}\text { Alessandra, } 57 \text { anos } \\
(2002-2008)\end{array}$ & $\begin{array}{l}\text { Pai, policial militar } \\
\text { (sem informação } \\
\text { sobre escolaridade), } \\
\text { mãe EF incompleto, } \\
\text { dona de casa. }\end{array}$ & $\begin{array}{l}\text { Escola } \\
\text { confessional }\end{array}$ & Professora na rede pública \\
\hline $\begin{array}{l}\text { Tiago, sem informação } \\
\text { de idade (2004-2008) }\end{array}$ & $\begin{array}{l}\text { Pai, EF completo, } \\
\text { eletricista } \\
\text { aposentado; mãe, } \\
\text { EF completo, dona } \\
\text { de casa }\end{array}$ & Escola privada & Professor rede pública \\
\hline
\end{tabular}




\begin{tabular}{|c|c|c|c|}
\hline $\begin{array}{l}\text { Pseudônimo, idade } \\
\text { e intervalo de anos } \\
\text { em que cursou CS }\end{array}$ & $\begin{array}{l}\text { Escolaridade e } \\
\text { ocupação dos pais }\end{array}$ & Onde fez EM? & $\begin{array}{l}\text { Destino após licenciatura } \\
\text { (ocupação e/ou outro } \\
\text { curso de graduação) }\end{array}$ \\
\hline $\begin{array}{l}\text { Gabriela, sem } \\
\text { informação de idade, } \\
\text { (sem informação } \\
\text { de ano de entrada - } \\
\text { formada em 20।0) }\end{array}$ & $\begin{array}{l}\text { Pais, EF incompleto, } \\
\text { pai pedreiro, mãe } \\
\text { 'vendedora' sem } \\
\text { maior especificação }\end{array}$ & $\begin{array}{l}\text { Escola pública e } \\
\text { privada com bolsa } \\
\text { parcial }\end{array}$ & $\begin{array}{l}\text { Professora em Instituto } \\
\text { Federal }\end{array}$ \\
\hline $\begin{array}{l}\text { Luísa, } 32 \text { anos (2006- } \\
2011)\end{array}$ & $\begin{array}{l}\text { Pai, balconista, } \\
\text { que "não quis } \\
\text { saber muito de } \\
\text { estudo", mãe, } \\
\text { sem informação } \\
\text { sobre escolaridade, } \\
\text { costureira e } \\
\text { esteticista. }\end{array}$ & $\begin{array}{l}\text { Escola privada, } \\
\text { bolsa parcial }\end{array}$ & Professora na rede pública \\
\hline $\begin{array}{l}\text { Joana, sem informação } \\
\text { de idade, (entrada em } \\
\text { 2005- sem informação } \\
\text { de ano de formatura) }\end{array}$ & $\begin{array}{l}\text { Pais com ES } \\
\text { completo, } \\
\text { professores que } \\
\text { também atuaram na } \\
\text { burocracia do PT e } \\
\text { em administrações } \\
\text { ligadas ao partido }\end{array}$ & Escola privada & Pequena empresária \\
\hline $\begin{array}{l}\text { Rafael, } 27 \text { anos, (2008- } \\
2013 \text { ) }\end{array}$ & $\begin{array}{l}\text { Pai e mãe com } \\
\text { EM completo, pai } \\
\text { vendedor e mãe } \\
\text { contadora em uma } \\
\text { concessionária de } \\
\text { veículos }\end{array}$ & Escola particular & $\begin{array}{l}\text { Terminou o Mestrado em } \\
\text { Sociologia, mas pretende } \\
\text { trabalhar com gastronomia. }\end{array}$ \\
\hline
\end{tabular}

Recebido em: 14/11/2018

Aprovado em: 13/05/2019 